\title{
Effect of cutting fluids on the tool life in turning and milling of construction steel
}

\author{
Andrey Dugin ${ }^{1}$, Lukas Volesky² \\ ${ }^{1}$ Department of Machining and Assembly, Faculty of Mechanical Engineering, Technical University of Liberec. \\ ${ }^{2}$ Centre for Nanomaterials, Advanced Technologies and Innovation, Technical University of Liberec \\ 461 17, Studentská 1402/2, Liberec 1, Czech Republic. \\ E-mail: andrey.dugin@seznam.cz, lukas.volesky@tul.cz
}

Using cutting fluids often enables an increase of cutting tool life. A large amount of cutting fluids produced in the European Union exists on the market of Czech Republic. It is quite difficult for purchasers of cutting fluids to acquire reliable test data about the performance of the fluids in industrial conditions and choose the best cutting fluid, the use of which will guarantee the longest tool life. In this regard comparative tests of cutting fluids were conducted at the laboratory of the Department of Machining and Assembly of the Technical University of Liberec to determine the effect of cutting fluids from different producers (from England, Germany, Norway and Switzerland) on tool life in turning and milling.

Keywords: Machining, Cutting fluid, Wear

\section{Acknowledgments \\ The paper was supported in part by the project OP VaVpI "Innovative products and environmental technologies", registration number $C Z .1 .05 / 3.1 .00 / 14.0306$.}

\section{References}

[1] JAYAL, A.D., BALAJI, A.K., SESEK, R., GAUL, A., LILLQUIST, D.R., (2007), Machining performance and health effects of cutting fluid application in drilling of A390.0 cast aluminum alloy, Journal of Manufacturing Processes, Vol. 9, No. 2, pp. 137 - 146.

[2] ROTELlA, G., DILlON JR., O.W., UMBRELLO, D., SETTINERI, L., JAWAHIR, I.S., (2014), The effects of cooling conditions on surface integrity in machining of Ti6Al4V alloy, International Journal of Advanced Manufacturing Technology, Vol. 71, No. 1 - 4, pp. 47 - 55.

[3] WEINERT, K., INASAKI, I., SUTHERLAND, J.W., WAKABAYASHI, T., (2004), Dry machining and minimum quantity lubrication, CIRP Annals - Manufacturing Technology, Vol. 53, No. 2, pp. 511 - 537.

[4] POPOV, A., DUGIN, A., (2013), Study of reasons of increased active force using coolant with uncut chip thickness, The International Journal of Advanced Manufacturing Technology, Vol. 70, No. 9 - 12, pp. 1 - 8.

[5] THEPSONTHI, T., HAMDI, M., MITSUI, K., (2009), Investigation into minimal-cutting-fluid application in high-speed milling of hardened steel using carbide mills, International Journal of Machine Tools and Manufacture, Vol. 49, No. 2, pp. $156-162$.

[6] DINIZ, A.E., MICARONI, R., (2007), Influence of the direction and flow rate of the cutting fluid on tool life in turning process of AISI 1045 steel, International Journal of Machine Tools and Manufacture, Vol. 47, No. 2, pp. $247-254$.

[7] KURAM, E., OZCELIK, B., BAYRAMOGLU, M., DEMIRBAS, E., SIMSEK, B.T., (2013), Optimization of cutting fluids and cutting parameters during end milling by using D-optimal design of experiments, Journal of Cleaner Production, Vol. 42, pp. 159 - 166

[8] NÁPRSTKOVÁ, N., CAIS, J., STANCEKOVÁ, D., (2014), Influence of Alsi7Mg0.3 alloy modification by Sb on the tool wear, Manufacturing Technology, Vol. 14, No. 1, pp. $75-79$.

[9] VASILKO, K., (2014), New experimental dependence of machining, Manufacturing Technology, Vol. 14, No. 1, pp. $111-116$.

[10] KOLARIK, K., GANEV, N., PALA, Z., BAKALOVA, T., (2009), Comparative study of experimental methods for evaluation of residual stress distribution, EAN 2009: 47th International Conference on Experimental Stress Analysis

[11] DUGIN, A., JERSAK, J., POPOV, A., (2014), Method for determining of the anti-adhesion ability of cutting fluids, Manufacturing Technology, Vol. 14, No. 2, pp. 145 - 149. 
[12] DUGIN, VOTOCEK, J., POPOV, A., (2014), Method for determining the tribological properties of the cutting fluid, Manufacturing Technology, Vol. 14, No. 2, pp. 149 - 153.

[13] JERSÁK, J., VRKOSLAVOVÁ, L., (2013), The influence of process fluids on the properties of the surface layer of machined components, Manufacturing Technology, Vol. 13, No. 4, pp. $466-473$.

[14] POPOV A, DUGIN A, (2013), Influence of Lubricant and Coolant Fluid on the Cutting Force in Small-Increment Planning, Russian Engineering Research, Vol. 33, No. 2, pp. 84 - 85.

[15] NATH, C., KAPOOR, S.G., SRIVASTAVA, A.K., IVERSON, J., (2013), Effect of fluid concentration in titanium machining with an atomization-based cutting fluid (ACF) spray system, Journal of Manufacturing Processes, Vol. 15 , No. 4, pp. $419-425$. 